\title{
Behaviour of reconstituted sand-sized particles in direct shear tests using PIV technology
}

\author{
Peerun. I $^{\text {i) }}$ Ong. D.E.L ${ }^{\text {ii) }}$ and Choo. C. iii) $^{\text {ii }}$ \\ i) Research Scholar*, ii) Director (Acting)*, iii) Associate Lecturer* \\ *Research Centre for Sustainable Technologies, Faculty of Engineering, Computing \& Science, \\ Swinburne University of Technology Sarawak Campus, Jalan Simpang Tiga 93350 Kuching, Sarawak, Malaysia.
}

\begin{abstract}
This paper presents a study on the mechanical behaviour of reconstituted tunnelling rock spoils carried out using direct shear test. The objective is to study the Mohr-Coulomb (MC) failure criteria of sand and sand-sized spoils of metagreywacke based on their respective particle shapes. Particle motions were tracked using Particle Image Velocimetry (PIV) technique. A remotely controlled camera was used to capture sequential images, which were then processed using GeoPIV to produce particle movement vectors. The captured vectors were analysed to detect notable sample behaviours such as dilation and contraction, as well as particle interlocking and breakage. It was found that factors affecting cohesion include: a) effect of particle shapes and surface roughness; b) effect of confining stress and c) effect of particle interlocking and breakages.
\end{abstract}

Keywords: Direct shear, GeoPIV, Cohesion, Interlocking, Particle breakage

\section{INTRODUCTION}

This paper focuses on Particle Image Velocimetry (PIV) technology used to analyse particle behaviours of soils during shearing. The authors scrutinise the following aspects, which are related to the soil frictional angle and cohesion: 1) influence of particle shapes and roughness; 2) confining pressure; 3) particle breakage.

\section{DIRECT SHEAR TESTING}

A four-stage shearing model developed by Li and Aydin (2010), as shown in Figure 1, was used in this study to describe each shearing stage during direct shear tests. The model is of relevance to direct shear tests on dense or compacted specimens.

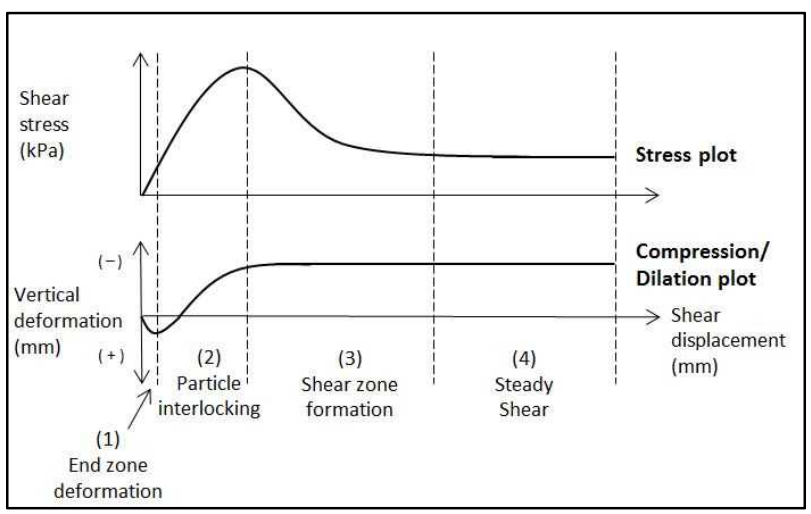

Fig. 1. Four stages during shearing (Li and Aydin, 2010)

\subsection{Shearing stages}

In Stage 1, 'end zone deformation' occurs when shearing starts and the sample contracts due to localised particle movements. The particles move into existing voids particularly at the ends of the shear zone, causing sample to contract. This stage ends when no further contractions are observed.

During contraction, the specimen is densified, creating more contact points between the particles. This signifies the initiation of 'particle interlocking' (Stage 2). In-contact particles along the shear zone have to surpass interlocking through localised dilation. This is observed as a volumetric expansion of the specimen. Particle interlocking is at a maximum when the slope of vertical deformation and horizontal displacement is steepest (see Fig. 1). This coincides with the occurrence of peak shear stresses. The degree of interlocking is dependent on the number of particles, particles shape and surface roughness.

'Shear zone formation' (Stage 3) starts from the peak stress where smaller particles fill voids, due to the expansion of the specimen during particle interlocking. Larger particles roll or rotate along the shear band. These dynamic particle movements initiate the formation of a loose layer called the shear zone. Shear stresses reduce due to post-peak strain softening.

With continued horizontal displacement, 'steady shear' (Stage 4) is achieved when a shear band is developed, exhibiting no further changes in shear 
stress or specimen volume. At this stage, the particles slide along the wavy surface with an equilibrium of dilation and contraction. The bottom half of the shear box moves with constant amplitude and reaches residual state (Li and Aydin, 2010).

\subsection{Particle Breakage}

Particle breakage during shearing has a notable impact on granular soil strength. Particle breakage is quantified from a breakage index which has been used by several researchers. Hardin (1985) described the breakage index as a method of quantifying the degree of fragmentation for crushable aggregates during loadings by conducting particle size distribution tests before and after. Xiao et al. (2014) reported that with increasing breakage index during loading or shearing, the peak and residual friction angles reduce considerably. Higher breakage index will increase the crushability of the specimen particles. Some of the factors affecting crushability are particle shape, hardness and size. Breakage is expected for angular particles as the stresses are concentrated at the edges. Lower void ratios will reduce contact stresses among particles (Djipov, 2012).

\section{TESTED SPECIMENS}

Two types of materials with different particle shapes and surface roughness were used as test specimens for this study. The first sample was sand consisting mainly of quartz particles. The quartz particles were observed to have rounded shape and smooth surface, as seen in Figure 2(a). The second sample consisted of sand-sized spoils of crushed metagreywacke. Petrographic analysis showed the presence of angular fine grained quartz, calcite, feldspar grains, rock fragments and clay minerals. The metagreywacke spoils consisted of angular shape and rougher particles. Figures 2(a) and 2(b) show the microscopic images of sand and metagreywacke, respectively.
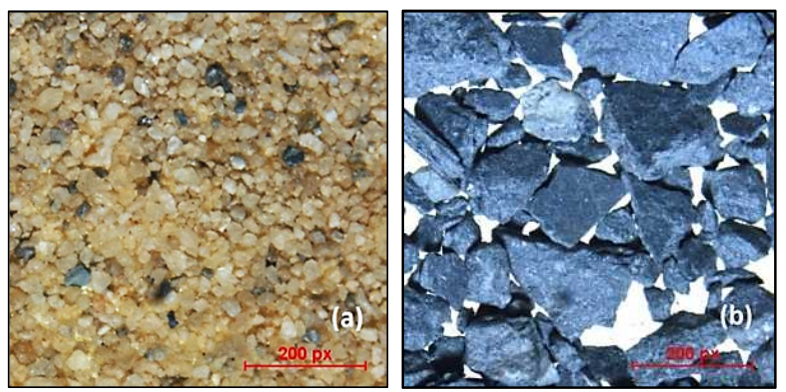

Fig. 2. Microscopic view of (a) sand (b) metagreywacke

Particle size distribution tests were conducted for both specimens according to ASTM D422-63 (2002) and classified using the Unified Soil Classification System (ASTM, 2000). Table 1 shows the granulometry results of both the scalped sand and scalped metagreywacke spoils.

Table 1. Physical properties of scalped specimens tested

\begin{tabular}{lll}
\hline Specimen & Lab Sand & $\begin{array}{l}\text { Meta- } \\
\text { greywacke }\end{array}$ \\
\hline$D_{60}(\mathrm{~mm})$ & 0.445 & 0.602 \\
\hline$D_{30}(\mathrm{~mm})$ & 0.222 & 0.257 \\
\hline$D_{10}(\mathrm{~mm})$ & 0.102 & 0.139 \\
\hline$D_{a v}(\mathrm{~mm})$ & 0.339 & 0.466 \\
\hline$C_{u}$ & 4.363 & 4.328 \\
\hline$C_{c}$ & 1.086 & 0.790 \\
\hline Classification & $\begin{array}{l}\text { Poorly graded } \\
\text { sand }\end{array}$ & $\begin{array}{l}\text { Poorly } \\
\text { graded sand- } \\
\text { sized spoils }\end{array}$ \\
\hline
\end{tabular}

\section{EQUIPMENT SETUP}

\subsection{Modified Direct Shear Apparatus}

The Geocomp ShearTracII apparatus was used during this study for direct shear testing of the two specimens. To capture images of the soil particles during the test, a specially fabricated transparent shear box was used, as shown in Figure 3. The transparent shear box was of diameter $63.4 \mathrm{~mm}$ and thickness $31.5 \mathrm{~mm}$, in accordance with ASTM D3080-03 (2003).

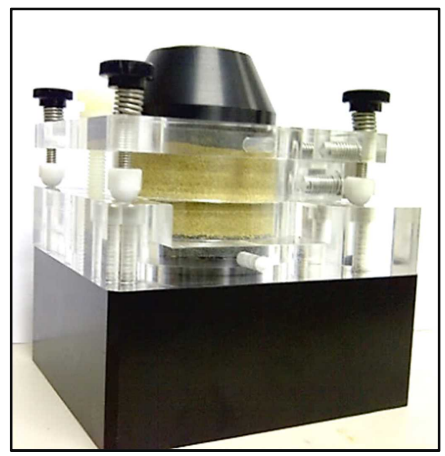

Fig. 3. Transparent shear box

\subsection{GeoPIV Software}

GeoPIV is a MATLAB module developed by White and Take (2002) which uses the principles of particle image velocimetry (PIV) to quantify observations of particle flow in geotechnical and geomechanical tests. The analysis and output results are defined by the following parameters: patch size, patch spacing, searchzone pixel and frame rate.

\section{METHODOLOGY}

\subsection{Sample preparation}

The specimens were oven-dried and scalped, in accordance with ASTM D3080-03 (2003). The specimens were scalped to contain only particles of sizes between $2.36 \mathrm{~mm}$ sieve and $75 \mu \mathrm{m}$. Direct shear 
test samples were prepared to be of diameter $63.4 \mathrm{~mm}$ and thickness $31.5 \mathrm{~mm}$. To obtain dense samples, the specimens were compacted into three layers of equal thickness, with 27 blows performed on each layer with the use of a tamping rod. The relative densities achieved for all the tested samples ranged from $80 \%$ to $90 \%$. Each sample was tested at effective normal stresses of $100 \mathrm{kPa}, 300 \mathrm{kPa}$ and $500 \mathrm{kPa}$, with horizontal displacements applied at a constant rate of $0.0017 \mathrm{~mm} / \mathrm{s}$. The maximum applied horizontal shear displacement was $15 \mathrm{~mm}$ for all tests.

\subsection{GeoPIV analysis}

Sequential images were remotely captured at 50 seconds interval using a 12 megapixel Canon EOS450D camera. A total of 176 images were obtained throughout the $15 \mathrm{~mm}$ shear displacement. The captured images were of dimensions $4272 \times 2848$ pixels. For PIV analysis, the region of interest was set at the central $60 \mathrm{~mm} \times 5 \mathrm{~mm}$ along the shear band for all the tests. Figure 4 shows a sample image captured during direct shear testing, with the region of interest highlighted.

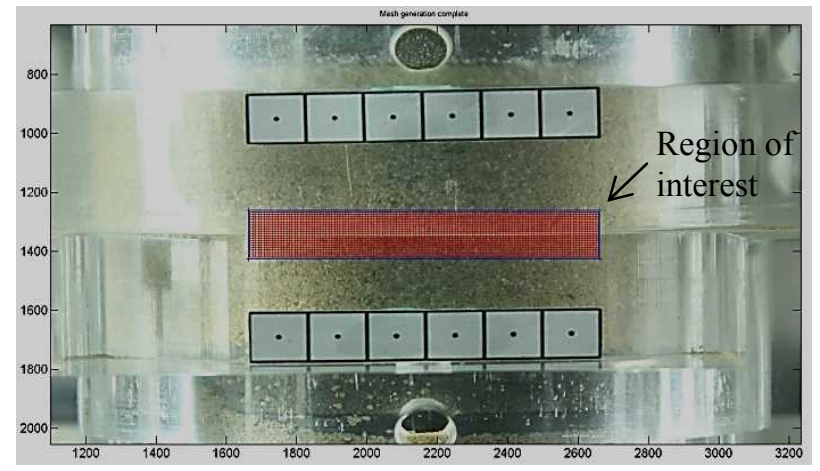

Fig. 4. Sample image used for GeoPIV analysis

To obtain the input parameters for GeoPIV analysis, parametric studies were conducted by varying the patch size, patch spacing, searchzone pixel and frame rate to obtain the optimum values for this study. Before analysing the set of images, a grid of test patches were drawn on the first image. The patches were then analysed in the subsequent images along the shear displacement to track their individual displacement vectors (White and Take, 2003). A $16 \times 16$ pixels patch was found most suitable for the analysis of the direct shear images by means of a parametric study.

Kelly (2014) reported that $50 \%$ overlap of consecutive patches would produce accurate results. Hence, an $8 \times 8$ pixels patch spacing (50\% overlap) was adopted. Searchzone pixel is the largest displacement vector which the software will examine between successive images. White and Take (2002) recommended that the value can be defined as half the difference between patch size and search patch. Hence, the searchzone pixel selected was $8 \times 8$ pixels.

Senatore et al. (2013) stated that the particle displacement must not be more than $25 \%$ of the patch size. For shearing rate of $0.0017 \mathrm{~mm} / \mathrm{s}$, a frame rate of 50 seconds was selected.

\section{RESULTS}

\subsection{Direct shear test results}

From Figures 5 and 6, the tested specimens exhibited an initial increase in shear stresses culminating in maximum peak shear stresses, before reducing to a residual shear stress.
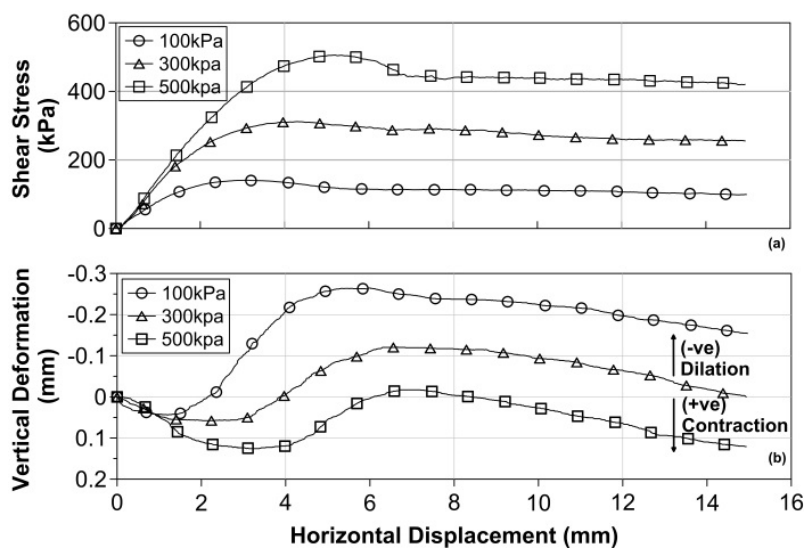

Fig. 5. Direct shear test results for sand

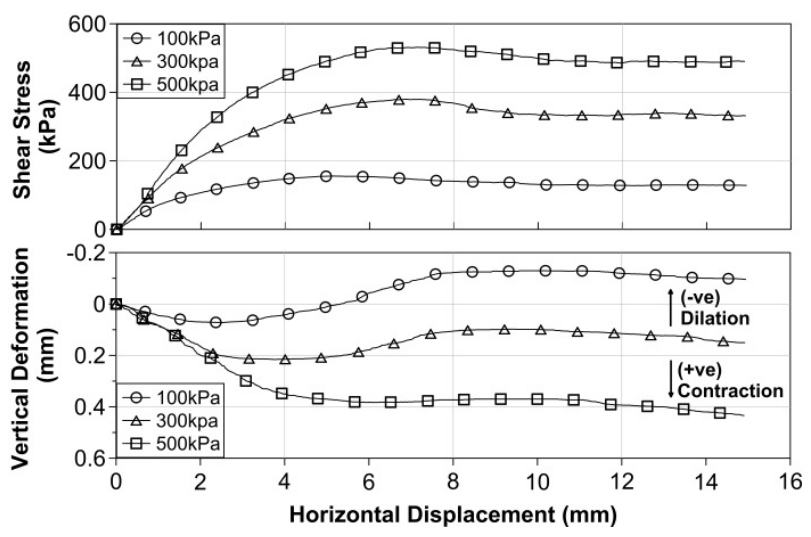

Fig. 6. Direct shear test results for spoils of metagreywacke

During the steady shear stage (Stage 4), all tested samples exhibited continued volumetric contraction with increasing horizontal displacement. This behaviour was more significant in the tested metagreywacke spoils (Figure 5). The angular metagreywacke particles implied that they were more susceptible to compression and breakages than the rounded sand particles (Djipov, 2012). The rounded sand particles, having less contact area, demonstrated lower shear stresses. Metagreywacke spoils achieved higher shear stress at peak state due to larger particle interlocking, attributed to the angularity of the particles. 


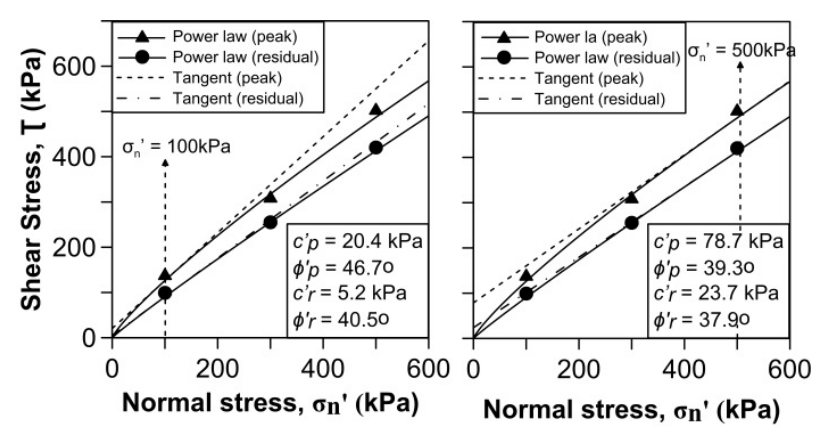

Fig. 7. Non-linear MC failure envelope for sand

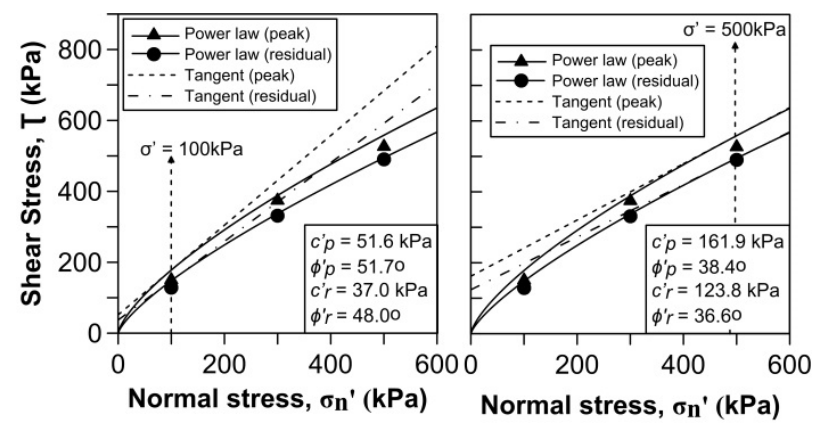

Fig. 8. Non-linear MC failure envelope for spoils of metagreywacke

The use of conventional best-fit linear MohrCoulomb envelopes to characterise the strength of granular materials may over-estimate material shear strength of the tested samples at low and high confining pressures, while under-estimating material shear strength at intermediate stresses (Choo and Ong, 2015). Hence, the strength behaviours of the tested samples were characterised using a non-linear failure criterion. A power law proposed by De Mello (1977) was used to characterise the nonlinear shear strength behaviour of the tested materials. Figures 7 and 8 show the nonlinear criterion using the power law function.

To demonstrate the degree of nonlinearity in the shear strengths of the tested samples, tangential approach developed by Yang and Yin (2004) was used. The degree of nonlinearity was illustrated through variations tangential parameters, $\phi^{\prime}{ }_{t}$ and $c^{\prime}{ }_{t}$ with increasing effective normal stresses. Tangents to the nonlinear failure envelopes were applied at 100 $\mathrm{kPa}$ and $500 \mathrm{kPa}$. Table 2 illustrates the tangential internal friction angle, $\phi_{t}{ }^{\prime}$ and tangential cohesion, $c_{t}{ }^{\prime}$ at peak and residual states for sand and metagreywacke spoils.

Table 2. Comparison of results of peak and residual shear strength for lab sand and metagreywacke

\begin{tabular}{|c|c|c|c|c|}
\hline Material & Sand & $\begin{array}{c}\text { Metagrey- } \\
\text { wacke }\end{array}$ & Sand & $\begin{array}{c}\text { Metagrey- } \\
\text { wacke }\end{array}$ \\
\hline $\begin{array}{c}\sigma_{n}{ }^{\prime} \\
(\mathrm{kPa})\end{array}$ & 100 & 100 & 500 & 500 \\
\hline$\phi_{t, p^{\prime}}\left(^{\circ}\right)$ & 46.7 & 51.7 & 39.3 & 38.4 \\
\hline$\phi_{t, r^{\prime}}\left(^{\circ}\right)$ & 40.5 & 48.0 & 37.9 & 36.6 \\
\hline$c_{t, p}{ }^{\prime}\left(^{\circ}\right)$ & 20.4 & 51.6 & 78.7 & 161.9 \\
\hline$c_{t, r^{\prime}}\left(^{\circ}\right)$ & 5.2 & 37.0 & 23.7 & 123.8 \\
\hline
\end{tabular}

The results showed that with increasing applied normal stresses, a reduction of $\phi_{t}{ }^{\prime}$ occurred in tandem with an increase in $c_{t}{ }^{\prime}$. For metagreywacke, this observation was consistent with observations made by Djipov (2012), where angular particles subjected to higher interlocking and breakages under confining pressures, which will result in a reduction in internal friction angle.

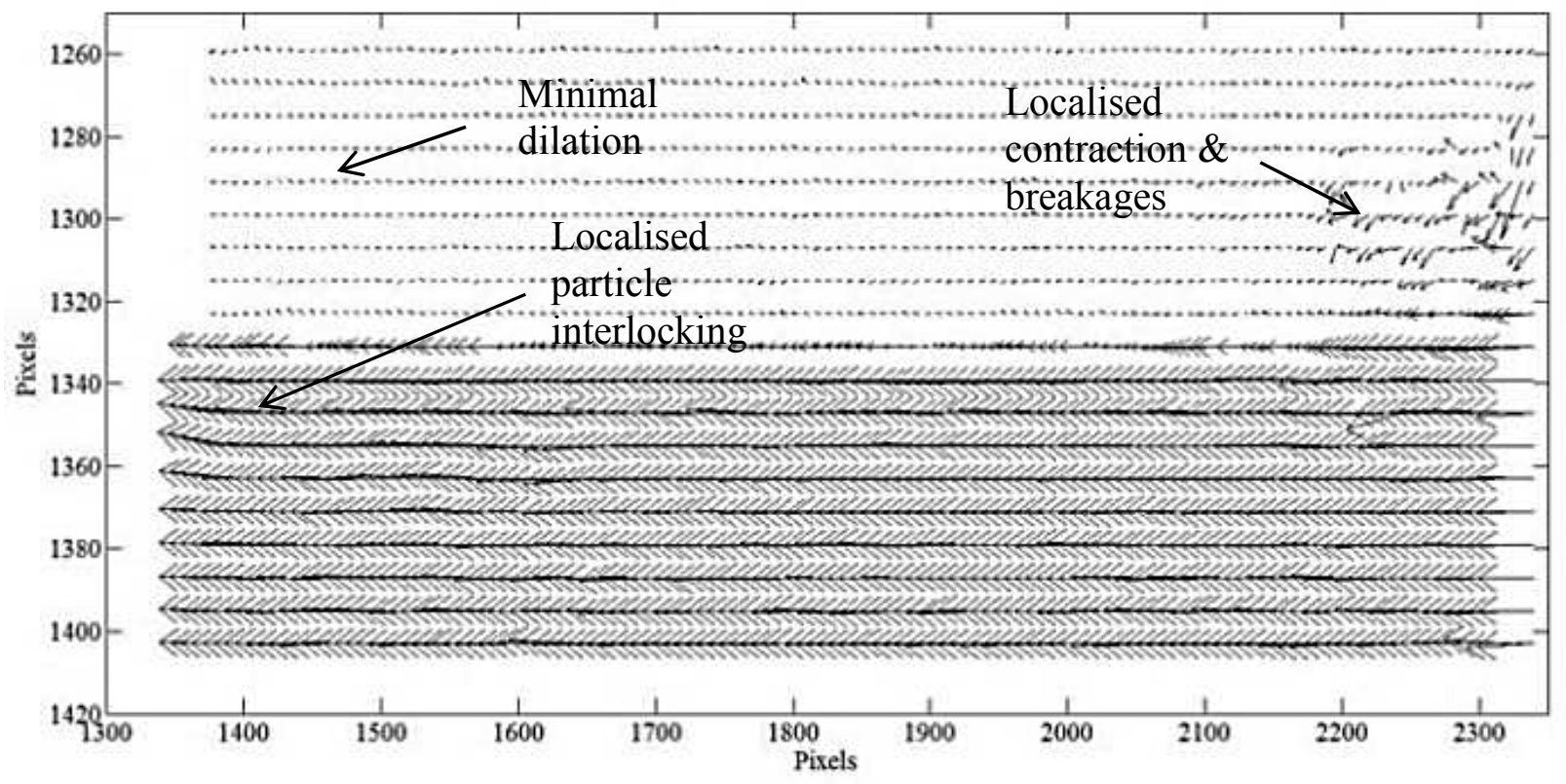

Fig. 9. GeoPIV result showing particle movements and interlocking at stage 2 for metagreywacke at $100 \mathrm{kPa}$ loading along the shear band 


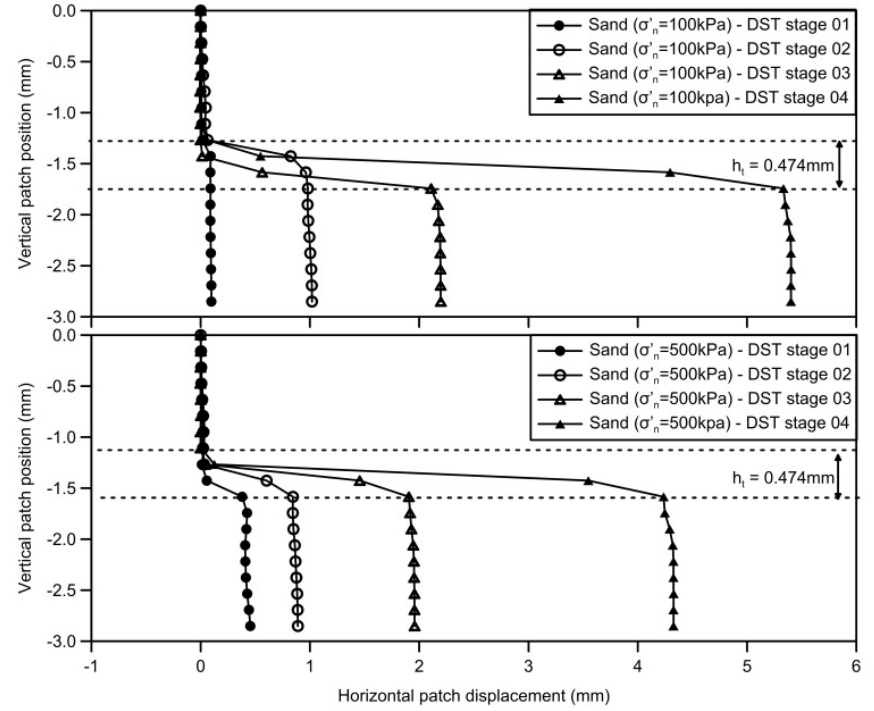

(a)

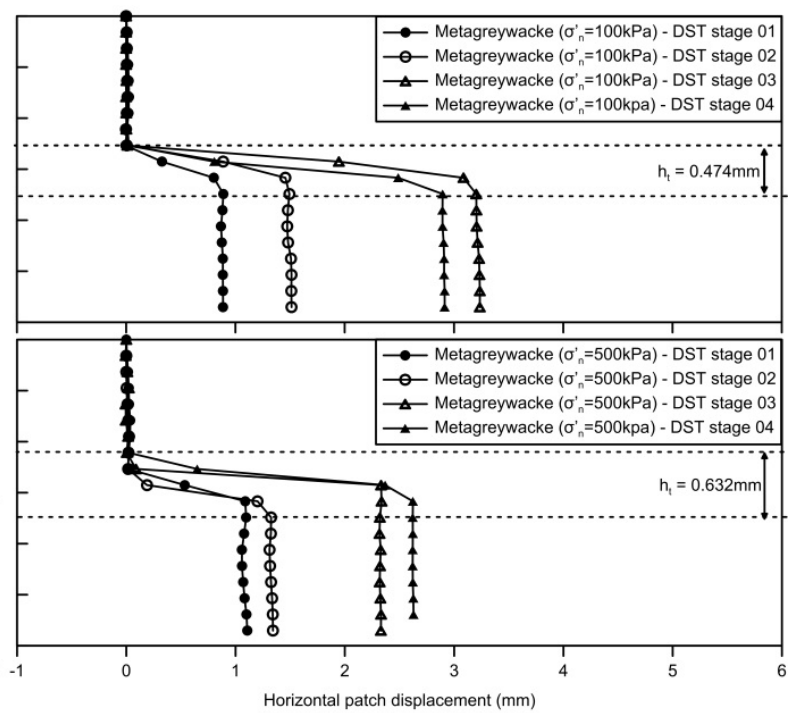

(b)

Fig. 10. Interpreted GeoPIV results for (a) lab sand and (b) metagreywacke

\subsection{GeoPIV results}

GeoPIV was used to study the mechanical behaviour of the tested specimens at different shearing stages such as particle rolling, interlocking or breakages. Figure 9 shows a typical GeoPIV result of a complete development of localized particle behaviour for metagreywacke spoils during particle interlocking (Stage 2) at $100 \mathrm{kPa}$ loading. Note that the aspect ratio of Figure 9 was modified for better illustration purposes.

Figure 10 shows interpreted results of the GeoPIV analysis for both specimens at different shearing stages under normal stresses of $100 \mathrm{kPa}$ and $500 \mathrm{kPa}$. An average displacement for each row was obtained from the vector files created by GeoPIV.

From this, plots of horizontal patch displacement versus vertical patch position were developed. The range of shear band thicknesses was indicated as the difference between the overlying vertical patch positions as a significant change in horizontal displacement with respect to the vertical patch position (DeJong and Westgate, 2009). The range of shear band thicknesses for both materials was found to be within $0.474 \mathrm{~mm}$ to $0.632 \mathrm{~mm}$. Generally larger shear bands were captured for metagreywacke spoils as opposed to sand. This was most likely due to the angularity and surface roughness of the metagreywacke spoils, as compared to the sphericity of the sand grains.

\section{DISCUSSIONS}

A comparison of the GeoPIV results showed that greater interlocking and breakages were identified in angular metagreywacke spoils. The broken angular particles filled up the voids and rearranged themselves within the structure while under compression. This behaviour occurred when the sample contracted initially, dilated and contracted again due to breakages. Greater interlocking and breakages produced higher shear stress and cohesion.

Interlocking intensified at higher confining pressure where the sample was subjected to contraction and particles were in greater contact with one another (Xiao et al., 2014). Figure 11 shows the shift in $\phi^{\prime}$ and $c^{\prime}$ due to changes in confining pressures, where increasing confining pressure produced higher apparent cohesion and a reduction in internal friction angle for metagreywacke spoils.

Samples with angular particles consisted of higher void ratio and were more vulnerable to breakages, which resulted in lower frictional angle and increase in cohesion (Xiao et al., 2014). This study showed that most likely and all others similarly, metagreywacke exhibited higher cohesion than sand due to the angularity of the metagreywacke spoils.

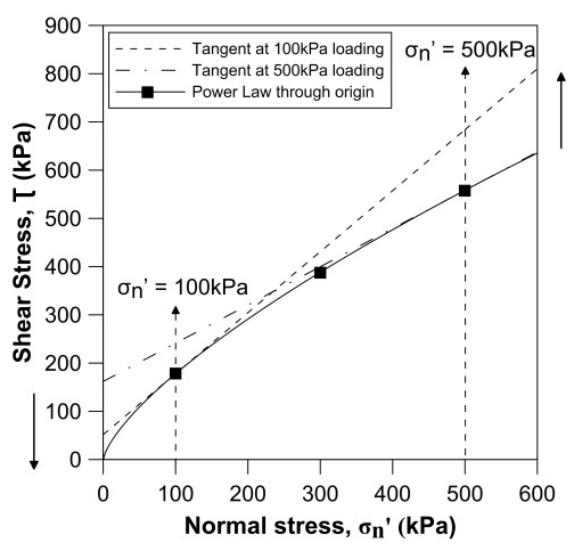

Fig. 11. Effect of confining pressure on cohesion using the tangential method for metagreywacke 


\section{CONCLUSION}

Particle behaviours of sand and reconstituted metagraywacke spoils were monitored using particle image velocimetry (PIV) on direct shear tests. The objective was to study the strength characteristics which are essential to soil arching, causing reduction in vertical stresses on installed pipes during pipejacking works. Direct shear tests and PIV results were paired and analysed to make the following interpretations: 1) Generally thicker shear band represents more particle interlocking; 2) Shear band thickness increases with increasing confining pressure; 3) Changes in MC internal friction angle is inversely proportional to cohesion with increasing normal stress; 4) Angular particles cause more particle interlocking and breakages than smooth, rounded ones, hence producing higher cohesion. More tests consisting of various materials will be conducted in the future to further verify the observations made in this paper.

\section{ACKNOWLEDGEMENTS}

The authors would like to extend their gratitude to Hock Seng Lee Bhd, Jurutera Jasa (Sarawak) Sdn Bhd, David White and Fredrik Phangkawira.

\section{REFERENCES}

1) ASTM. (2000): Standard Practice for Classification of Soils for Engineering Purposes (Unified Soil Classification System), ASTM D2487-00, West Conshohocken, PA.

2) ASTM. (2002): Standard test method for particle size analysis of soils, ASTM D422-63, West Conshohocken, PA.

3) ASTM. (2003): Standard test method for direct shear test of soils under consolidated drained conditions, ASTM D3080-03, West Conshohocken, PA.

4) Choo, C. S. and Ong, D. E. L. (2015): Evaluation of pipejacking forces based on direct shear testing of reconstituted tunnelling rock spoils, J. Geotech. Geoenviron. Eng., 10.1061/(ASCE)GT.1943-5606.0001348, 04015044.

5) DeJong, J. T. and Westgate, Z. J. (2009): Role of initial state, material properties, and confinement condition on local and global soil-structure interface behaviour, $J$. Geotech. Geoenviron. Eng. 2009.135:1646-1660.

6) De Mello, V. F. B. (1977): Reflections on design decisions of practical significance to embankment dams, Geotechnique, 27 (3), pp. 281-354.

7) Djipov, D. N. (2012): Effects of particle breakage on the compression and shear behavior of carbonate sand, 1st Civil and environmental engineering student conference, Imperial College London.

8) Hardin, B. O. (1985): Crushing of soil particles, J. Geotech. Engrg., 10.1061/(ASCE)0733-9410(1985)111:10(1177), 1177-1192.

9) Kelly, P. (2014): Soil structure interaction and group mechanics of vibrated stone column foundations, University of Sheffield.

10) Li, Y. R. and Aydin, A. (2010): Behavior of rounded granular materials in direct shear: Mechanisms and quantification of fluctuations, Engineering Geology, Elsevier.

11) Senatore, C., Wulfmeier, M., Vlahinic, I., Andrade, J. and Iagnemma, K. (2013): Design and implementation of a particle image velocimetry method for analysis of running gear-soil interaction, Journal of Terramechanics, vol. 50, no. 5-6, ScienceDirect, pp. 311-326.

12) White, D. J. and Take, W.A. (2002): GeoPIV: Particle Image Velocimetry (PIV) software for use in geotechnical testing, Cambridge University Engineering Department Technical Report.

13) White, D. J., Take, W.A. and Bolton, M. D. (2003): Soil deformation measurement using particle image velocimetry (PIV), Geotechnique 53, No. 7, 619-631.

14) Xiao, Y., Liu, H., Chen, Y. and Jiang, J. (2014): Strength and deformation of rockfill material based on large-scale triaxial compression tests. II: Influence of particle breakage, Journal of Geotechnical and Geoenvironmental Engineering.

15) Yang, X. L. and Yin, J. H. (2004): Slope stability analysis with nonlinear failure criterion, J. Eng. Mech., 130 (3), pp. 267-73. 